\title{
A Comparison of Yield Between High- and Low-intensity Management for Three Watermelon Cultivars
}

\author{
Wenhua Lu ${ }^{1}$ J.V. Edelson, Jim A. Duthie, and B. Warren Roberts \\ Wes Watkins Agriculture Research and Extension Center, Oklahoma State \\ University, Lane, OK 74555
}

Additional index words. cucurbit, ploidy, plant survival, melon aphid, cucumber beetle, squash bug, anthracnose

\begin{abstract}
Factors of crop management such as irrigation, cultivation, cultivar selection, and control of insect pests and plant diseases play important roles in watermelon production. To gain a better understanding of how intensity of crop management affects yield, we conducted a comparative study contrasting high and low intensity management in 1997, 1999, and 2000. High-intensity management (HM) included the use of trickle irrigation, black plastic mulch, insecticides, and fungicides, not used under low-intensity management (LM). We examined the effects of management intensity on watermelon productivity, the variation in such effects among watermelon cultivars, and the mediating effect of survival of watermelon plants, abundance of insect pests, and incidence of anthracnose (\% leaves with anthracnose lesions). The results indicated that HM produced $100 \%$ greater marketable fruit yield per area and marketable fraction of total fruit than LM in 2 out of 3 years. The effect of management intensity on plant survival was related to this effect on yield in 1 out of 2 years, and contributed to the latter by increasing weight and number of marketable fruit per plant under HM. We detected no significant effect of abundance of insect pests and incidence of anthracnose on yield. There was variation in the effect of management intensity on yield among watermelon cultivars in 1 out of 3 years. The triploid 'Gem Dandy' showed great differences in yield between HM and LM in 2 years, producing on average $28.9 \mathrm{Mg} \cdot \mathrm{ha}^{-1}$ of marketable fruit yield under $\mathrm{HM}$ compared to

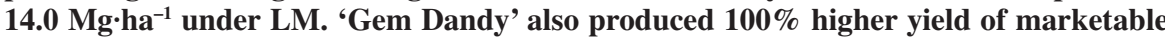
fruit per area, per plant, and marketable fraction of total fruit than the open-pollinated diploid 'Allsweet' or the diploid hybrid 'Sangria.' Each year during the 3-year study, all three cultivars had a similar density of insect pests, incidence of anthracnose, and plant survival after transplant and at harvest. This study provided information on the collective impact of multiple aspects of watermelon management on yield.
\end{abstract}

Crop management activities including soil fertilization, irrigation, cultivation, and control of insect pests and plant diseases play important roles in determining costs and returns of crop production (Metcalf and Luckmann, 1994). For profitable production of watermelon, Citrullus lanatus (Thunberg) Matsumura and Nakai, it is important to consider cultivar, irrigation, fertilization, and uses of herbicides, insecticides, and fungicides (Bolin and Brandenberger, 2001; Hochmuth et al., 2001). A question frequently asked by watermelon farmers is "What difference does the intensity of crop management make in determining yield and how great is the profit difference when using different tactics of management?" We therefore conducted a field study contrasting high and low management intensity in 1997, 1999, and 2000. High-intensity management included the use of soil fertilization, weed control,

Received for publication 29 Nov. 2001. Accepted for publication 28 July 2002. Approved for publication by the Oklahoma Agriculture Experimental Station. This research was funded in part by the Hatch programs and a USDA-CSRESS special grant.

${ }^{1}$ To whom reprint requests should be addressed. Phone: 580-889-7343; fax: 580-889-7347; E-mail: wenhua@etal.uri.edu black plastic mulch on planting beds, trickle irrigation, insecticides, and fungicides. Lowintensity management included the use of soil fertilization and weed control.

Previous studies have focused on the effects of one, two, or rarely three management factors on watermelon yield. Yield or net return is different among irrigation strategies (Battikhi and Hill, 1986; de Andrade et al., 2001; Srinivas et al., 1989a, 1989b). Plastic mulch not only increases yield (Soltani et al., 1995), but also suppresses aphid populations (Farias-Larios and Orozco-Santos, 1997a, 1997b). Systemic insecticides (Foster and Brust, 1995; Pair, 1997) reduce insecticide usage and suppress cucumber beetle [Acalymma vitattum (Fab.) (Coleoptera: Chrysomelidae)] and squash bug [Anasa tristis (Degeer)(Hemiptera: Coreidae)] populations. Keinath and Duthie (1998) have reviewed simple effects of application of fungicide on watermelon productivity. Amin and Ullasa (1981) found positive correlation between anthracnose and yield loss. Yield is higher using either irrigation or plastic mulch or both (Al-Gosaibi, 2001; Bhella, 1988; Ghawi and Battikhi, 1986). Although beneficial, these studies do not evaluate simultaneously the combined effects of several management practices and analyze the collective effects of these aspects on yield.
We hypothesized that HM would produce higher marketable fruit yield than LM in both weight and number. Our goals were to examine whether there were yield differences because of different intensity levels of watermelon management and if so, which management tactics contributed to these yield differences. Therefore, we tried to identify the effect of management intensity on the survival rate of watermelon plants, on the density of insect pests, and on the incidence of plant diseases. The melon aphid Aphis gossypii Glover (Hemiptera: Aphidae), the striped cucumber beetle, and the squash bug are common insect pests of watermelon (Robinson and Decker-Walters, 1997; Webb et al., 2001). Anthracnose is a common watermelon disease caused by the fungal pathogen Collectotrichum orbiculare (Berk. and Mont.) (Hopkins and Latin, 2001; Keinath and Duthie, 1998; Robinson and Decker-Walters, 1997). These were the targets of pest control and deployment of insecticides and fungicides in our study. We hypothesized that the insect pests would be more abundant under LM because we used insecticides in HM. Further we hypothesized that LM would have higher incidence of anthracnose because we did not use fungicides in LM. Because the use of plastic mulch, irrigation, insecticides, and fungicides should provide better plant growth, we anticipated higher survival of watermelon plants under HM throughout the cropping season.

In addition, because seed costs of watermelon cultivars vary and therefore affect management decisions, we selected three watermelon cultivars representing diploid inbred, diploid hybrid, and triploid hybrid types. 'Allsweet' is an open-pollinated diploid cultivar with large fruit $(13 \mathrm{~kg})$ and low seed cost ( $\$ 2 / 1000$ seeds). 'Sangria' is a diploid hybrid with large fruit $(10 \mathrm{~kg})$ and moderate seed cost ( $\$ 35 / 1000$ seeds). 'Gem Dandy' is a triploid hybrid, with medium size fruit (7 kg) and high seed cost (\$170/1000 seeds). We hypothesized that there would be genetic (cultivar) differences in yield and expected higher yield with the triploid cultivar.

Although triploid hybrids have been reported to be more resistant to anthracnose than diploid open-pollinated and hybrid cultivars (Elmstrom and Crall, 1981; Henderson, 1977) abundance of the melon aphid differs little among cultivars (MacCarter and Habeck, 1973). The cultivars we chose were not bred specifically for insect resistance, but have similar anthracnose resistance. We therefore expected no significant differences in insect abundance and disease incidence among cultivars. Previous studies in watermelon resistance to insects or diseases utilized no additional management tactics. We subjected the cultivars to different management strategies and expected cultivar responses to differ between HM and LM.

Overall, information on variation among cultivars and the effect of management intensity on watermelon productivity has been scattered among numerous studies that simplified management schemes to one to three factors. We therefore examined: 1) the effect of manage- 
ment intensity on watermelon fruit yield; 2) the variation among watermelon cultivars in yield due to management intensity; and 3) the effect of survival of watermelon plants, abundance of insect pests, and incidence of anthracnose on yield. Our purpose is to answer the first of the farmers' questions and present the collective impact of multiple aspects of watermelon management on yield. We will address the second question about the profit differences between HM and LM in another paper. Results from this study will be fundamental in developing profit/cost estimates for HM and LM that will provide a basis for recommendations to watermelon growers.

\section{Materials and Methods}

All experiments were conducted at the Wes Watkins Agriculture Research and Extension Center at Lane, Okla., in 1997, 1999, and 2000. Fields were different each year, but size, design, and orientation from east to west were consistent over years. The soil was a Bernow sandy loam (fine-loamy, siliceous, thermic Glossic Paleudalf). High-intensity management (HM) included the use of black plastic mulch, trickle irrigation, insecticides, and fungicides, not used under low-intensity management (LM). Each replicate was $36.6 \times 5.5 \mathrm{~m}$ in size, and was divided into two main plots $(18.3 \times 5.5 \mathrm{~m})$ for random application of either HM or LM treatment. Each main plot contained three subplots $(6.1 \times 5.5 \mathrm{~m})$, each randomly planted to one cultivar of 30 plants. Watermelon seedlings were transplanted in three rows within a subplot, with plants $0.6 \mathrm{~m}$ apart within a row. A planting of soybean [Glycine max (L.) Merrill] $(2.4 \times 5.5 \mathrm{~m})$ separated main plots, and a space of $36.6 \times 5.5 \mathrm{~m}$ separated replicates with a planting of corn (Zea mays L.) $(36.6 \times$ $3.0 \mathrm{~m}$ ) in the middle.

This protocol was repeated simultaneously in 6,4 , and 6 blocks, respectively, each year. Therefore, this was completely randomized block design with a split-plot arrangement of 2 treatments $\times 3$ cultivars $\times 6$ (4) blocks for each year. Four major indices were measured: fruit yield, plant survival, insect density, and anthracnose incidence. Analyses of variance for all four indices were based on the same split-plot design, using PROC MIXED (SAS Institute, 1998) with block and treatment $x$ block as RANDOM factors. Least significant difference (LSD) was computed for differences between main plots (treatment), among subplots (cultivar), and interaction, by LSD $=t_{0.025}$ $x$ standard error (SE). The LSD values were presented only when an effect of either main plot, or subplot, or interaction was significant for any of the four measurement indices. In the formula, $t_{0.025}$ was a $t$ value at $\alpha=0.025$ for a degree of freedom corresponding to each main plot or subplot factor or interaction. The SE on the difference between two least squares means was obtained from using LSMEANS statement in PROC MIXED.

Both HM and LM treatments received the same soil preparation and dates of transplanting (9 June, 20 May, and 7 June, respectively, each year) within a year. Use of plastic mulch can increase soil temperature, maintain soil moisture, and control weeds. We conducted intensively weed control in both HM and LM plots so that the effects of plastic mulch would be restricted to soil temperature and moisture. The watermelon seeds germinated in watermoistened peat pellets before transplanting. Field assistants conducting the insect surveys, visual assessments of disease, plant counts, and harvest remained the same within a year, but varied among years.

Yield per area. Watermelon fruit was harvested twice at $\approx 2$ months after transplanting in three consecutive weeks in 1997 and 1999 so as to equalize plant growth and fruit maturity, but only once 7 weeks after transplanting in 2000. At harvest, marketable and cull fruits were weighed and counted for each block/ cultivar/treatment to estimate fruit yield. A fruit was marketable if it had symmetrical shape and no signs of disease or physical damage. Yield of total fruit was the sum of marketable and cull fruit yields. We recorded both weight and number of marketable and total fruits, and calculated the marketable fraction of total fruit by weight (\% weight of marketable fruit/weight of total fruit) and the marketable fraction of total fruit by number (\% number of marketable fruit/number of total fruit). The statistically significant $\alpha$ level at $P=0.05$ was chosen to be lenient because of the robust nature of field experiments for all six measurements of fruit yield each year.

Plants and yield per plant. In 1997 and 1999 , the number of watermelon plants surviving both after transplant (13 June and 8 June, respectively) and at harvest (22 Sept. and 30 Aug., respectively) were recorded for each block/cultivar/treatment. Plant survival was estimated as both percentage (surviving number/total planted) and density (surviving number $/ \mathrm{m}^{2}$ ). To reveal how plant survival related to yield per area, yield per plant was estimated as a ratio of the total yield to the total number of surviving plants at harvest for each block/cultivar/treatment. Because of low survival rate each year in all plots, we replanted seedlings to the initial 30 plants per subplot (cultivar) after the first survival count. This was necessary to ensure harvest and provided two independent estimates for plant survival. Multiple harvests allowed similar growth periods for the replanted transplants. As before the statistically significant $\alpha$ level was at $P=$ 0.05 for plant survival after transplant, plant survival at harvest, marketable fruit weight per plant, and marketable fruit number per plant.

Insects. The following insect densities were monitored at 7-d intervals: 1) the melon aphid adults and nymphs; 2) the cucumber beetle adults; 3 ) the squash bug adults and nymphs; and 4) the squash bug egg masses. We examined one plant/block/cultivar/treatment each week for insects from transplant to vining stage, and $0.25 \mathrm{~m}^{2} / \mathrm{block} /$ cultivar/treatment from vining stage to harvest, using a $0.5 \times$ 0.5 -m quadrant. All plants or quadrants were randomly selected in the center row of each subplot. Watermelon seedlings with three to four leaves marked the start of a vining stage $(\approx 1$ month after transplant). We treated the data collected before vining as though they were also collected from the $0.5 \times 0.5-\mathrm{m}$ quadrants because the distance between two plants was $0.6 \mathrm{~m}$, about the space between two quadrants. Mean densities were averaged over sampling dates for each block/cultivar/treatment. The statistically significant $\alpha$ level was at $P=$ 0.0005 to be conservative because of the robust nature of field experiments on the means for all four insect pest measurements.

Anthracnose. To ensure occurrence of anthracnose in the experimental plots, the plots were artificially inoculated by placing crimped oat kernels infested with the anthracnose pathogen in the center row of each cultivar for both HM and LM treatments 3 to 4 weeks after transplant. To measure the incidence of anthracnose, we first visually assessed the entire canopy within each row/block/cultivar/ treatment for the percentage of all leaves with lesions that are typical of anthracnose. These lesions constituted anthracnose when dark brown spots with clear-cut edges appeared on a leaf. A scale was then used to rate the percentage of brown spotted leaves relative to all leaves. The scale was based on the arcsine of square-root transformation (Little and Hills, 1978 ) with scores of integer values from 0 to 15. The transformation can improve the homogeneity of residual variance and provide a robust field assessment for a percentage range instead of percentage per se. The disease rating was conducted once or twice a week from 3 to 5 weeks after transplanting (21 July, 11 June, and 13 July, respectively for 1997, 1999, and 2000) through harvest. There were a total of 6,11 , and 5 ratings respectively each year, but the data were averaged from the same week; therefore, there were only 6 ratings in 1999 . Mean scores of anthracnose were averaged over sampling dates and rows for each block/cultivar /treatment. The statistically significant $\alpha$ level was at $P=0.0005$ to be conservative on the means. We converted and reported the mean incidence (\%) of leaves with lesions from the mean scores after statistical analyses.

\section{Results}

Yield per area. HM significantly increased fruit yield of watermelon in 2 out of 3 years. In 1997, weight of marketable fruit, weight of total fruit, marketable fraction by weight, number of marketable fruit, number of total fruit, and marketable fraction by number were all significantly higher in plots under HM than LM (Table 1). In 1999, the differences in fruit yield between HM and LM were not statistically significant (Table 1). In 2000, weight of marketable fruit, weight of total fruit, marketable fraction by weight, number of marketable fruit, and marketable fraction by number were all significantly higher in plots under HM than LM (Table 1).

There was significant interaction between cultivar and management intensity in yield in 1997. The cultivars differed significantly under HM (cultivar $\times$ treatment interaction) in weight of marketable fruit, marketable fraction by weight, number of marketable fruit, and marketable fraction by number. 
Table 1. Effects of watermelon management intensity on marketable fruit weight, total fruit weight, marketable fraction of total fruit by weight, number of marketable fruit, number of total fruit, and marketable fraction of total fruit by number in each of three field experiments at Lane, Okla.

\begin{tabular}{|c|c|c|c|c|c|c|c|c|}
\hline Year & Cultivar & $\begin{array}{c}\text { Management } \\
\text { intensity }\end{array}$ & $\begin{array}{c}\text { Wt of } \\
\text { marketable fruit } \\
\left(\mathrm{Mg} \cdot \mathrm{ha}^{-1}\right)\end{array}$ & $\begin{array}{c}\text { Wt of } \\
\text { total fruit } \\
\left(\mathrm{Mg} \cdot \mathrm{ha}^{-1}\right)\end{array}$ & $\begin{array}{l}\text { Marketable } \\
\text { fraction by } \\
\text { wt }(\%)\end{array}$ & $\begin{array}{c}\text { No. of } \\
\text { marketable fruit } \\
(1000 / \text { ha })\end{array}$ & $\begin{array}{l}\text { No. of } \\
\text { total fruit } \\
(1000 / \mathrm{ha})\end{array}$ & $\begin{array}{c}\text { Marketable } \\
\text { fraction by } \\
\text { no. }(\%)\end{array}$ \\
\hline \multirow[t]{9}{*}{1997} & \multirow[t]{2}{*}{ Allsweet } & High & 27.9 & 42.0 & 63.1 & 4.2 & 10.4 & 40.0 \\
\hline & & Low & 9.3 & 23.5 & 34.3 & 1.5 & 7.3 & 18.4 \\
\hline & \multirow[t]{2}{*}{ Sangria } & High & 18.9 & 33.9 & 55.9 & 3.1 & 10.5 & 30.0 \\
\hline & & Low & 12.2 & 24.6 & 43.9 & 1.9 & 6.3 & 29.5 \\
\hline & \multirow[t]{2}{*}{ Gem Dandy } & High & 28.6 & 43.8 & 64.7 & 7.2 & 15.1 & 47.6 \\
\hline & & Low & 6.2 & 19.7 & 27.9 & 1.5 & 8.8 & 18.3 \\
\hline & & 10.3 & 10.6 & 19.3 & 1.5 & 1.8 & 14.1 \\
\hline & \multicolumn{2}{|l|}{$\operatorname{LSD}(\mathrm{df}=20)_{\text {cultivar }}$} & NS & NS & NS & 1.2 & 1.7 & NS \\
\hline & \multicolumn{2}{|l|}{ LSD $(\mathrm{df}=20)_{\text {treatment } \times \text { cultivar }}$} & 9.3 & NS & 17.1 & 1.4 & NS & 12.7 \\
\hline \multirow[t]{7}{*}{1999} & \multirow[t]{2}{*}{ Allsweet } & High & 4.8 & 50.9 & 8.9 & 0.6 & 16.9 & 3.6 \\
\hline & & Low & 2.9 & 33.8 & 5.0 & 0.5 & 15.3 & 2.2 \\
\hline & \multirow[t]{2}{*}{ Sangria } & High & 1.4 & 52.1 & 3.1 & 0.2 & 20.6 & 1.3 \\
\hline & & Low & 0.6 & 35.7 & 1.2 & 0.1 & 16.3 & 0.4 \\
\hline & \multirow[t]{2}{*}{ Gem Dandy } & High & 22.3 & 59.9 & 37.3 & 5.2 & 26.3 & 21.0 \\
\hline & & Low & 12.6 & 46.5 & 22.1 & 2.9 & 22.1 & 12.2 \\
\hline & $\operatorname{LSD}(\mathrm{df}=12)$ & & 7.3 & NS & 8.6 & 1.5 & 7.1 & 5.1 \\
\hline \multirow[t]{8}{*}{2000} & \multirow[t]{2}{*}{ Allsweet } & High & 12.4 & 58.2 & 21.4 & 1.7 & 18.9 & 9.0 \\
\hline & & Low & 4.9 & 41.5 & 12.3 & 0.8 & 18.3 & 4.7 \\
\hline & \multirow[t]{2}{*}{ Sangria } & High & 19.7 & 70.2 & 27.9 & 2.7 & 17.9 & 15.5 \\
\hline & & Low & 7.8 & 59.3 & 13.0 & 1.1 & 20.5 & 5.2 \\
\hline & \multirow[t]{2}{*}{ Gem Dandy } & High & 35.9 & 57.1 & 62.6 & 6.3 & 15.7 & 41.1 \\
\hline & & Low & 23.3 & 54.0 & 42.8 & 4.8 & 20.3 & 23.9 \\
\hline & $\operatorname{LSD}(\mathrm{df}=5)_{\text {treatment }}$ & & 6.6 & 7.7 & 11.4 & 1.1 & NS & 6.9 \\
\hline & $\operatorname{LSD}(\mathrm{df}=20)_{\text {cultivar }}$ & & 5.0 & 7.0 & 8.2 & 0.8 & NS & 5.1 \\
\hline
\end{tabular}

In 1997, number of marketable fruit and number of total fruit was significantly greater for 'Gem Dandy' (Table 1). In 1999, weight of marketable fruit, marketable fraction by weight, number of marketable fruit, number of total fruit, and marketable fraction by number were all significantly greater for 'Gem Dandy' (Table 1). In 2000, weight of marketable fruit, weight of total fruit, marketable fraction by weight, number of marketable fruit, and marketable fraction by number were all significantly greater for 'Gem Dandy' (Table 1). Regardless of management intensity, in both 1999 and 2000 the triploid cultivar 'Gem Dandy' had greater marketable yield than either 'Sangria' or 'Allsweet'.

Plants and yield per plant. There was evidence that the survival of plants contributed to the effect of management intensity on yield in 1997: the percentage or the density (number $/ \mathrm{m}^{2}$ ) of watermelon plants surviving was significantly higher under HM than LM after transplant and at harvest (Table 2) when there was significantly higher yield under HM (Table1). In 1999, there were no significant differences in plant survival between HM and LM after transplant and at harvest (Table 2) when there was no significant yield difference (Table1). Therefore, differences in plant survival appear to be related to differences in yield between HM and LM in 1997 and 1999.

The effect of management intensity on weight and number of marketable fruit per plant was comparable to that on plant survival in 1997. A watermelon plant produced greater weight and more marketable fruits in HM plots than in LM plots in 1997, but not in 1999 (Table 2). This effect of management intensity varied significantly among cultivars in weight and number of marketable fruit per plant (cultivar $\times$ treatment interaction) in 1997. 'Gem Dandy' produced greater weight per plant than 'Allsweet' and a higher number of marketable fruit per plant than the other cultivars under HM in 1997 (Table 2). Regardless of management intensity, 'Gem Dandy' produced significantly greater marketable fruit weight per plant in 1999 and higher marketable fruit number per plant in both 1997 and 1999 than the other cultivars.

Insects. The number of insect pests was not significantly different between HM and LM plots in any year. Aphid populations were low in 1997 and 1999, reaching a peak towards the end of the cropping season (Fig. 1A). HM had more aphids at the last count in 1999, an unexpected result. There was no detectable aphid population in 2000. Abundance of cucumber beetles appeared to peak in the middle of the cropping season in all 3 years (Fig. 1B). Squash bugs adults and nymphs were most abundant toward the later part of the cropping season, as were the number of its egg masses, in 1997 and 2000 when the population density was low in general (Fig. $1 \mathrm{C}$ and D). However, oviposition as indicated by abundance of egg masses reached its maximum in the middle of the cropping season in 1999 (Fig. 1D), resulting in the increasing peak of adults and nymphs of the squash bug in the later part of the same season (Fig. 1C). The number of each insect pest was similar among cultivars each year.

Anthracnose. The incidence of anthracnose was only significantly different between HM and LM plots in 1999. The mean incidence of leaves with anthracnose lesions at the time of the second harvest was $\approx 2 \%$ and $90 \%$ in 1999 in plots under HM and LM, respectively (Fig. 2). In 1997 and 2000, the incidence of leaves with anthracnose lesions was low and the percentage of leaves with lesions appeared slightly greater in plots under HM (Fig. 2). The anthracnose incidence was similar among cultivars each year.

Table 2. Effects of watermelon management intensity on plant survival after transplant, plant survival at harvest (number $/ \mathrm{m}^{2}$ ), weight of marketable fruit per plant, and number of marketable fruit per plant in each of two field experiments at Lane, Okla.

\begin{tabular}{|c|c|c|c|c|c|c|}
\hline \multirow{2}{*}{ Year } & \multirow[b]{2}{*}{ Cultivar } & \multirow{2}{*}{$\begin{array}{c}\text { Management } \\
\text { intensity }\end{array}$} & \multicolumn{2}{|c|}{ Plant survival $\%\left(\right.$ no. $\left./ \mathrm{m}^{2}\right)$} & \multicolumn{2}{|c|}{ Marketable fruit per plant } \\
\hline & & & After transplant & $\overline{\text { At harvest }}$ & Wt (kg) & No. \\
\hline \multirow[t]{6}{*}{1997} & Allsweet & High & $95.0(0.85)$ & $90.6(0.81)$ & 3.56 & 0.53 \\
\hline & & Low & $43.3(0.39)$ & $72.8(0.65)$ & 1.47 & 0.23 \\
\hline & Sangria & High & $97.8(0.88)$ & $92.2(0.83)$ & 2.30 & 0.38 \\
\hline & & Low & $42.2(0.38)$ & $69.4(0.62)$ & 2.38 & 0.36 \\
\hline & Gem Dandy & High & $76.7(0.69)$ & $81.7(0.73)$ & 4.00 & 1.00 \\
\hline & & Low & $32.2(0.29)$ & $67.2(0.60)$ & 1.18 & 0.28 \\
\hline \multicolumn{3}{|c|}{$\operatorname{LSD}(\mathrm{df}=5)$} & $25.9(0.23)$ & $13.3(0.12)$ & 1.76 & 0.26 \\
\hline \multicolumn{3}{|c|}{$\operatorname{LSD}(\mathrm{df}=20)_{\text {cultivar }}$} & NS & NS & NS & 0.20 \\
\hline \multicolumn{3}{|c|}{ LSD $(\mathrm{df}=20)_{\text {treatment } \times \text { cultivar }}$} & NS & NS & 1.50 & 0.22 \\
\hline \multirow[t]{6}{*}{1999} & \multirow[t]{2}{*}{ Allsweet } & High & $97.5(0.88)$ & $78.3(0.70)$ & 0.67 & 0.09 \\
\hline & & Low & $92.5(0.83)$ & $80.0(0.72)$ & 0.38 & 0.06 \\
\hline & \multirow[t]{2}{*}{ Sangria } & High & $94.2(0.85)$ & $69.2(0.62)$ & 0.25 & 0.03 \\
\hline & & Low & $90.8(0.82)$ & $70.8(0.64)$ & 0.08 & 0.01 \\
\hline & \multirow[t]{2}{*}{ Gem Dandy } & High & $95.8(0.86)$ & $73.3(0.66)$ & 3.41 & 0.79 \\
\hline & & Low & $97.5(0.88)$ & $75.8(0.68)$ & 1.94 & 0.46 \\
\hline \multicolumn{3}{|c|}{$\operatorname{LSD}(\mathrm{df}=12)_{\text {cultivar }}$} & NS & NS & 1.06 & 0.22 \\
\hline
\end{tabular}



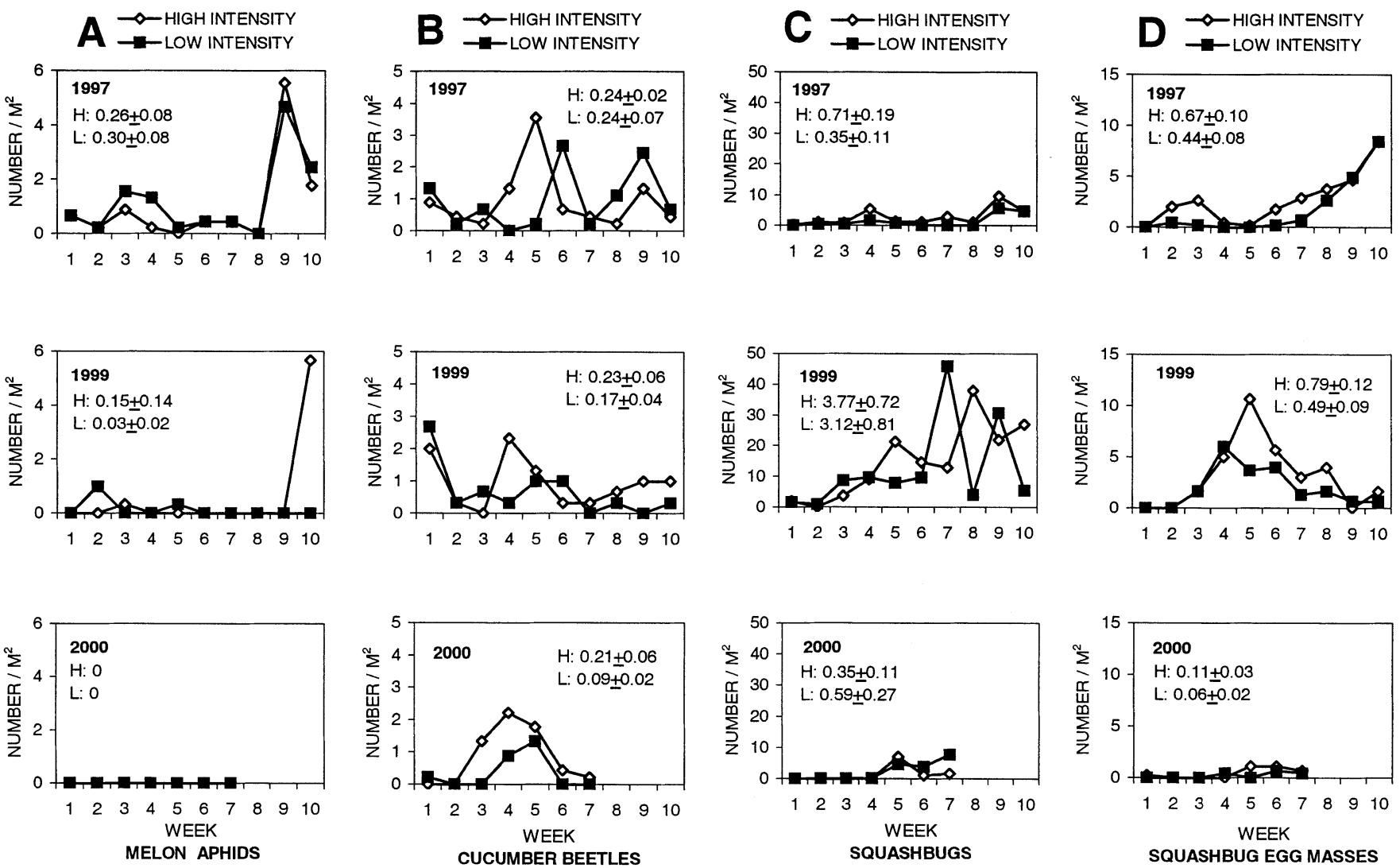

Fig. 1. Abundance of insect pests between high and low intensity management for watermelon in each of three field experiments at Lane, Okla. Mean density (number $/ \mathrm{m}^{2}$ ) of (A) melon aphid adults and nymphs, (B) cucumber beetle adults, (C) squash bug adults and nymphs, and (D) egg masses of squash bugs were averaged over replicate blocks and cultivars (week 1 was 1-2 weeks after transplant at 17 June, 27 May, and 20 June, respectively, for each experiment), with overall means \pm SE indicated.

\section{Discussion}

Over the 3 years, HM doubled marketable fruit weight and number per area. This gain in yield is brought about by increasing the marketable fraction of total fruit by either weight or number per area, both of which were $100 \%$ higher in plots under HM than LM. Weight and number of total fruit in HM plots were increased by $<40 \%$ over the three years. Marketable yields per area ranging from 0.6 to $35.9 \mathrm{Mg} \cdot \mathrm{ha}^{-1}$ (540 to $32,100 \mathrm{lb} /$ acre from Table 1) were comparable to Oklahoma statistics, including home growers and hobby production (Oklahoma Agriculture Statistics Service, 2001), which ranged from 3.5 to 12.2 $\mathrm{Mg} \cdot \mathrm{ha}^{-1}$ (3,000 to $\left.10,000 \mathrm{lb} / \mathrm{acre}\right)$. The marketable yield was very low when compared with the total yield in 1999 (Table 1). There were substantial numbers of "bottle-necked" fruit, probably the result of extremely hot weather and poor pollination. Hot weather can cause fruit disfiguring and sunburn. The lack of pollination may have resulted from a loss of honeybee pollinators that year and may have been exacerbated by adverse impact of high temperature on flower setting (Roberts et al., 1998). Our fruit sizes (weight per fruit) were smaller than those listed by seed companies, because we graded all fruits that were small, but in good shape and not defective, as marketable, which may not be the case for seed companies. Nevertheless, the data reflect genetically based differences in fruit size; 'Allsweet' and 'Sangria' are larger than 'Gem Dandy' for all physiologically and pathologically sound fruits $(6.7,7.3$, and $4.2 \mathrm{~kg}$, respectively), even though these fruits were smaller than seed company "averages" (13, 10, and $7 \mathrm{~kg}$, respectively).

This is also the first study to show how the effects of management intensity varied among different cultivars. We found that not only the cultivars differed in yield, but also their responses to management intensity were variable. In 1997 'Allsweet' and 'Gem Dandy' had greater yields under HM than LM, but 'Sangria' had similar yield between HM and LM (Table 1). Such variation in response to management intensity among cultivars is expected and the information is useful for those who make decisions in management intensity. One would expect that cultivars that do not respond well to HM should only be used in LM systems.

Plant survival and yield appear to be related in 1997. When there was a significant effect of management intensity on plant survival (Table 2), the differences in fruit yield between HM and LM were significant (Table 1). Plant survival therefore contributes to the effect of management intensity on fruit yield by increasing the weight and number of marketable fruit per plant by $>90 \%$ on average over both years. Our finding is consistent with those of Srinivas et al. (1989c), NeSmith (1993), Nerson et al.
(1994), Duthie et al. (1999b), Bracy and Parish (1997), Sanders et al. (1999), and NeSmith and Duval (2001) that yield per area or per plant increases with plant survival or density. However, higher survival of plants in our study was also associated with a higher marketable fraction of total fruit. This is inconsistent with findings that plant survival has no effect on marketable fraction of fruit biomass (Duthie et al., 1999a); very likely all three cultivars in our study responded differently from 'Sugar Baby' used by Duthie et al. (1999a).

There was no evidence that the effect of management intensity on yield was mediated by differences in management intensity for insects or disease. Control of insect pests and plant disease was an integral part of our HM, but was not related to differences in yield between HM and LM in this study. This finding does not agree with observations of lower insect populations when using plastic mulch (FariasLarios and Orozco-Santos, 1997a, 1997b) and lower disease incidence when using fungicides (Keinath and Duthie, 1998). Because of low abundance of insects in all 3 years (Fig. 1) and low incidence of anthracnose in 2 out of 3 years (Fig. 2), we did not expect significant effect or interactions of insect abundance or anthracnose incidence with fruit yield. In 1999, high incidence of anthracnose (Fig. 2) surprisingly caused little yield loss in LM. Perhaps the development of disease was slow and only reached a high level of incidence at the end of 

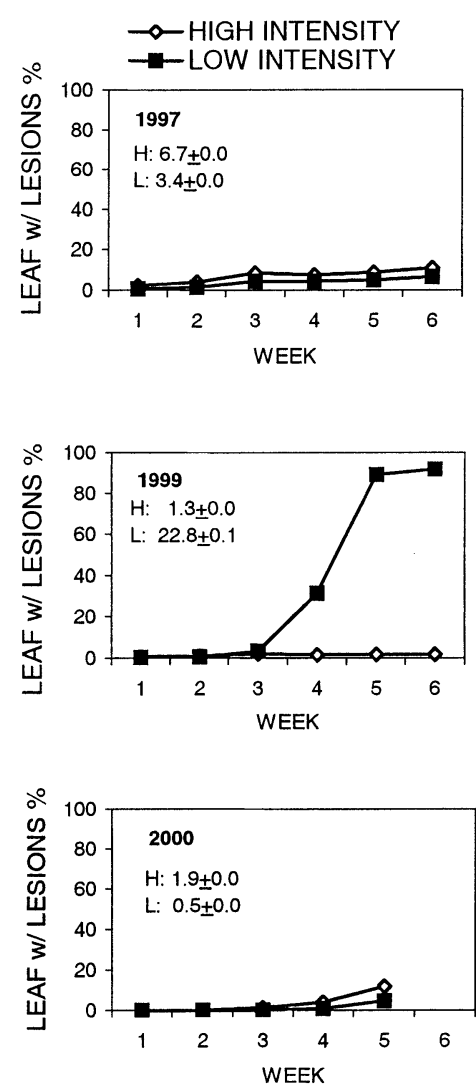

Fig. 2. Incidence of anthracnose (\%) between high and low intensity management for watermelon in each of three field experiments at Lane, Okla. Mean percentage of leaves with anthracnose lesions was averaged over sampling dates within a week, rows, replicate blocks, and cultivars (week 1 was 5-6 weeks after transplant at 21 July, 25 June, and 13 July, respectively, for each experiment), with overall

the cropping season, therefore, too little time to affect fruit yield. Fungicides may have suppressed watermelon growth (Keinath, 2000) because there was no significant difference in both fruit yield and plant survival between HM and LM in 1999. Similar yields between HM and LM may have also been due to climatic conditions because a high proportion of plants (2 blocks) was lost and both HM and LM plots had much lower marketable fruit yield in 1999. Because there was no effect of management intensity on incidence of anthracnose in both 1997 and 2000, hot and dry conditions may play a role in low incidence of anthracnose. The higher degree of anthracnose in 1999 may have been the result of climatic differences from 1997 and 2000.

Black plastic mulch and trickle irrigation used in HM may be key factors in explaining the differences in yield and in survival of plants, as previous research (Bhella, 1988; Pier and Doerge, 1995a, 1995b; Srinivas et al., 1989a, 1989b, 1989c) have documented higher yield when using either black plastic mulch or trickle irrigation or both. Climatic differences among years may have resulted in the lesser effect of management intensity on yield and plant survival in 1999. Decline of honeybee pollinator activity in extremely hot weather (Roberts et al., 1998) may have reduced watermelon pollination and flower set, and therefore the yield difference between HM and LM.

Regardless of the intensity of crop management, 'Gem Dandy' produced the most marketable fruit per area or per plant among the three cultivars in terms of either weight or number. It is not surprising that the three cultivars had similar insect density, disease incidence, and plant survival. Previous research has indicated that the cultivar 'Allsweet' and many other cultivars attracted the same population level of cucumber beetles and squash bugs (Pair and Bruton, 1998). Although many polyploid watermelon cultivars are more resistant to anthracnose (Henderson, 1977), to bacterial fruit blotch (Hopkins and Elmstrom, 1995), and to yellow vine disease (Pair and Bruton, 1998) than diploid open-pollinated and hybrid cultivars, we found the triploid 'Gem Dandy' was not superior in resistance to anthracnose in comparison to 'Allsweet' and 'Sangria.'

In conclusion, HM increased yield of marketable fruit in 2 out of 3 years by $100 \%$ or more. This effect of management intensity on yield varied among cultivars of different genotype and ploidy in 1 out of 3 years. The effect of management intensity on yield was mediated by the effect of management intensity on plant survival in 1997. By increasing weight and number of marketable fruit per plant, the management intensity also increased the marketable yield per area by either weight or number, and increased the marketable fractions by either weight or number. Management intensity had few detectable influences on insect abundance. The incidence of anthracnose was significantly higher in LM in only 1 out of 3 years, but it did not cause significant yield loss. The cultivars had similar abundance of insects, incidence of anthracnose, and survival rate. 'Gem Dandy' had the greatest yield regardless of the intensity of crop management in 1999 and 2000. This study will allow further evaluation of profit/ cost ratio and aid in optimizing watermelon production. An economic analysis comparing HM with LM is underway.

\section{Literature Cited}

Al-Gosaibi, A.M. 2001. Effect of water regime and mulch on growth and yield of watermelon and minerals contents under drip irrigation. Arab Univ. J. Agr. Sci. 9(1):1-9.

Amin, K.S., and B.A. Ullasa. 1981. Effect of thiophanate on epidemic development of anthracnose and yield of watermelon. Phytopathology 71:20-22.

Battikhi,A.M., and R.W. Hill. 1986. Irrigation scheduling and watermelon yield model for the Jordan Valley. J. Agron. Crop Sci. 157(3):145-155.

Bhella, H.S. 1988. Effect of trickle irrigation and black mulch on growth, yield, and mineral composition of watermelon. HortScience 23: 123-125.

Bolin, P. and L. Brandenberger (eds.). 2001. Cucurbit integrated crop management. Oklahoma Coop Ext. Serv. E-853. Oklahoma State Univ., Stillwater.

Bracy, R.P. and R.L. Parish. 1997. Row number, seed spacing, and fertilizer rate effects on melon production. J. Veg. Crop Production 3(1):47-57.

de Andrade, A.S., J.A. Frizzone, E.A. Bastos, M.J.
Cardoso, and B.H.N. Rodrigues. 2001. Optimal irrigation strategies for watermelon crop. Pesquisa Agropecuaria Brasileira 36(2):301-305.

Duthie, J.A., J.W. Shrefler, B.W. Roberts, and J.V. Edelson. 1999a. Plant density-dependent variation in marketable yield, fruit biomass, and marketable fraction in watermelon. Crop Sci. 39(2):406-412.

Duthie, J.A., B.W. Roberts, J.V. Edelson, and J.W. Shrefler. 1999b. Plant density-dependent variation in density, frequency, and size of watermelon fruits. Crop Sci. 39(2):412-417.

Elmstrom, G.W. and J.W. Crall. 1981. Quality, yield, and disease resistance evaluations of 'Sugarlee' watermelon. HortScience 16:285.

Farias-Larios, J. and M. Orozco-Santos. 1997a. Color polyethylene mulches increase fruit quality and yield in watermelon and reduce insect pest populations in dry tropics. Gartenbauwissenschaft 62(6):255-260

Farias-Larios, J. and M. Orozco-Santos. 1997b. Effect of polyethylene mulch color on aphid populations, soil temperature, fruit quality, and yield of watermelon under tropical conditions. N.Z. J. Crop Hort. Sci. 25(4):369-374.

Foster, R.E. and G.E. Brust. 1995. Effects of insecticides applied to control cucumber beetles (Coleoptera: Chrysomelidae) on watermelon yields. Crop Sci. 14:619-624.

Ghawi, I. and A.M. Battikhi. 1986. Watermelon (Citrullus lanatus) production under mulch and trickle irrigation in the Jordan Valley. J. Agron. Crop Sci. 156:225-236.

Henderson, W.R. 1977. Effects of cultivar, polyploidy, and "reciprocal" hybridization on characters important in breeding triploid seedless watermelon hybrids. J. Amer. Soc. Hort. Sci. 102:293-297.

Hochmuth, G.J., E. Kee, T.K. Hartz, F.J. Dainello, and J.E. Motes. 2001. Chapter 5. Cultural management: 78-97. In: D.N. Maynard (ed.). Watermelons: Characteristics, production, and marketing. ASHS Press, Alexandria, Va.

Hopkins, D.L. and R.X. Latin. 2001. Chapter 7. Diseases, p. 109-130. In: D.N. Maynard (ed.). Watermelons: Characteristics, production, and marketing. ASHS Press, Alexandria, Va.

Keinath, A.P. 2000. Effect of protectant fungicide application schedules on gummy stem blight epidemics and marketable yield of watermelon. Plant Dis. 84(3):254-260.

Keinath, A. P. and J. A. Duthie. 1998. Yield and quality reductions in watermelon due to anthracnose, gummy stem blight, and black rot. Recent Res. Dev. Plant Pathol. 2:77-90.

Little, T.M. and F.J. Hills. 1978. Agricultural experimentation. Wiley, New York.

MacCarter, L.E. and D.H. Habeck. 1973. The melon aphid: Screening varieties and introductions for resistance. J. Econ. Entomol. 66(5): 1111-1112.

Metcalf, R.L. and W.H. Luckmann. 1994. Introduction to insect pest management (3rd edition). Wiley-Interscience, New York.

Nerson, H., Y. Burger, and R. Berdugo. 1994. High plant density and irrigation increase watermelon yield grown for seed consumption. Adv. Hort. Sci. 8(2):101-105.

NeSmith, D.S. 1993. Plant spacing influences watermelon yield and yield components. HortScience 29:885-887.

NeSmith, D.S. and J.R. Duval. 2001. Fruit set of triploid watermelons as a function of distance from a diploid pollinizer. HortTechnology 36(1):60-61.

Oklahoma Agriculture Statistics Service. 2001. Oklahoma Agriculture Statistics 2000. Oklahoma Dept. of Agr., Oklahoma City.

Pair, S.D. 1997. Evaluation of systemically treated squash trap plants and attracticidal baits for early- 
season control of striped and spotted cucumber beetles (Coleoptera: Chrysomelidae) and squash bug (Hemiptera: Coreidae) in cucurbit crops. J. Econ. Entomol. 90(5):1307-1314.

Pair, S. D., and B. D. Bruton. 1998. Relationship of watermelon genotype and ploidy to incidence of yellow vine disease: 248-251. In: J. McCreight (ed.). Proceedings of Cucurbitaceae '98. ASHS Press, Alexandria, Va.

Pier, J. W., and T. A. Doerge. 1995a. Nitrogen and water interactions in trickle-irrigated watermelon. Soil Sci. Soc. Amer. J. 59:145-150.

Pier, J.W., andT.A. Doerge. 1995b. Concurrentevaluation of agronomic, economic, and environmental aspects of trickle-irrigated watermelon production. J. Environ. Quality 24:79-86.

Roberts, W., J. Edelson, J. Duthie, J. Shrefler, J. Enis, S. Smith, W. O'Hern, N. Roe, G. Cornforth, and T. Matthews. 1998. Multi-cropping cattle and watermelon in the southern plains. p. 32-33. In: Sustainable agriculture research and education: southern region 1998 annual report. Southern region SARE. Griffin, Ga.

Robinson, R. W., and D. S. Decker-Walters. 1997. Cucurbits. Crop production science in horticulture series 6. CAB Intl., New York.

Sanders, D.C., J.D. Cure, and J.R. Schultheis. 1999. Yield response of watermelon to planting density, planting pattern, and polyethylene mulch HortScience 34:1221-1223.

SAS Institute. 1998. SAS 6.11 for Windows. SAS Inst., Cary, N.C.

Soltani, N., J.L. Anderson, and A.R. Hamson. 1995. Growth analysis of watermelon plants grown with mulches and rowcovers. J. Amer. Soc. Hort. Sci. 120(6):1001-1009.

Srinivas, K., D.M. Hedge, and G. V. Havanagi. 1989a Plant water relations, canopy temperature, yield and water-use efficiency of watermelon Citrullus lanatus (Thunb.) Matsum et Nakai under drip and furrow irrigation. J. Hort. Sci. 64:115-124.

Srinivas, K., D.M. Hedge, and G.V. Havanagi. 1989b. Growth analysis of watermelon (Citrullus lanatus) (Thunb) Matsum et Nakai) in relation to drip and furrow irrigation. Indian J. Agron. 34(2):222-227.

Srinivas, K., D.M. Hedge, and G. V. Havanagi. 1989c. Effect of nitrogen and plant population on yield, quality, nutrient uptake, and water use of watermelon (Citrullus lanatus Matsum et Nakai) under drip and furrow irrigation. Gartenbauwissenschaft 54(5):220-223.

Webb, S.E., D.G. Riley, and G.E. Brust. 2001. Chapter 8. Insect and mite pests: 131-149. In: D.N. Maynard (ed.). Watermelons: Characteristics, production, and marketing. ASHS Press, Alexandria, Va. 